Piotr Łukomski*

\title{
Ewolucja zjawiska bezosobowej tyranii z perspektywy teorii ewolucji kulturowej
}

\section{The Evolution of the Phenomenon of Impersonal Tyranny from the Perspective of the Theory of Cultural Evolution}

Stowa kluczowe: zachowania społeczne, biurokracja, style rzadzenia, ewolucja kulturowa, Arendt

Keywords: social behavior, bureaucracy, styles of governance, cultural evolution, Arendt

\begin{abstract}
Abstrakt: Wartykule przedstawiam analizę krytycznego ujęcia zjawiska nowoczesnej biurokracji Hannah Arendt w teoretycznych ramach ewolucji kulturowej. Biurokracja, rozumiana jako bezrefleksyjna racjonalizacja ludzkich zachowan, jest procesem prowadzacym do minimalizacji sfery publicznej, rozumianej jako domena swobodnie uprawianej polityki, a w konsekwencji do powstania bezosobowej tyranii. Współczesne koncepcje ewolucji kulturowej pozwalaja na poszukiwanie nowego modelu eksplanacji tego zjawiska, które przekształca rozumienie polityki i samego człowieka w świecie współczesnym.
\end{abstract}

Abstract: In the paper I present an analysis of the critical approach to the phenomenon of modern bureaucracy by Hannah Arendt within the theoretical framework of cultural evolution. Bureaucracy, understood as the thoughtless rationalization of human behavior, is a process leading to the minimization of the public sphere, understood as the domain of freely performed politics, and consequently to the creation of impersonal tyranny. Contemporary concepts of cultural evolution allow to search for a new model of explanation of this phenomenon, which transforms the understanding of politics and man himself in the contemporary world.

* ORCID ID: https://orcid.org/0000-0002-5307-616X, doktor, Zakład Teorii Polityki, UniwersytetZielonogórski.Zajmuje się teorią zachowań politycznych wkontekście różnych paradygmatów racjonalności oraz ich ewolucją, w tym modelem racjonalności opartym na teorii władzy sądzenia. 


\section{Wprowadzenie}

Przestrzeń kulturowa, rozumiana jako sfera informacji przekazywanej w ramach różnych systemów symbolicznych, może być traktowana jako zbiór możliwych wzorców zachowań, które mogą być realizowane w danym czasie jako obowiązkowe (konieczne). Percepcja społeczna każdego z tych wzorców jest uwikłana w dany kontekst historyczny, który narzuca jego rozumienie oraz wiąże ludzką świadomość, przekształcając dany układ zachowań w naturalny sposób bycia. Kontekst historyczny to przede wszystkim system znaczeń, który z punktu widzenia teorii informacji odpowiada jej aspektowi semantycznem ${ }^{1}$. W niniejszej analizie uwzględnimy natomiast syntaktykę wzorów zachowań, która próbuje uchwycić ich aspekt formalny, pozwalający na analizę zachowań poza określonym momentem historycznym. W tym konkretnym przypadku przedstawimy zjawisko, które w terminologii Arendt nosi nazwę gramatyki władzy, a perspektywa wyznaczona przez ten termin jest próbą pokazania ewolucji możliwych układów władzy². Tyrania jest oczywiście pojęciem zaczerpniętym z klasycznej teorii politycznej i w zależności od układów pojęciowych, w którychfunkcjonowało, możeprzywoływać różne konotacje ${ }^{3}$. W teorii Arendt zjawisko tyranii jest przede wszystkim pewnym układem zależności, który prowadzi do redukcji sfery publicznej, rozumianej jako sfera swobodnego działania. W takim określeniu sfery publicznej pojawia się pewna redundancja pojęciowa, wynikającaz faktu, że o działaniu możemy mówić tylko wtedy, gdy jest swobodne ${ }^{4}$. Dodatkowa charakterystyka pozwala nam jednak na większa precyzję pojęciową, bez przywoływania wszystkich rozróżnień, które Arendt przedstawia w analizach zachowań zawartych w Kondycji ludzkiej5.

Tyrania w nowoczesnym rozumieniu posiada, w przeciwieństwie do klasycznej, charakter bezosobowy, który wynika z przekształceń społecznych związanych z rewolucją technologiczną6. Społecznym odpowiednikiem technologii w społeczeństwie nowoczesnym stała się biurokracja rozumiana jako model rządzenia ludźmi, najczęściej przedstawiana w terminach inżynierii społecznej. Biurokracja, w rozumieniu Arendt,

\footnotetext{
${ }^{1}$ Por. M. Hetmański, Epistemologia informacji, Warszawa 2013, s. 101 i n.

2 Por. H. Arendt, O rewolucji, przekł. M. Godyń, D.W. Totus, Kraków 1991, s. 16-18.

3 Por. L. Strauss, O tyranii, przekł. P. Armada, A. Górnisiewicz, Kraków 2009, s. 22 i n.

${ }^{4}$ G. Kateb, Political action: its nature and advantages, [w:] D. Villa (red.), The Cambridge

Companion to Hannah Arendt, Cambridge University Press 2002.

${ }^{5}$ H. Arendt, Kondycja ludzka, przekł. A. Łagodzka, Warszawa 2000, s. 12 i n.

${ }^{6}$ Tamże, s. 240 i n.
} 
jest wcieleniem idei racjonalności instrumentalnej, ale nie jest przy tym równoważna, pod względem zakresu, z administracyjnymi funkcjami instytucji państwa 7 . Z jednej strony jest ona bowiem ostateczną formą uspołecznienia człowieka, a z drugiej strony jest sposobem myślenia (ideą), który narzuca rozpatrywanie każdego człowieka (tożsamości i zachowań) wyłącznie w kategoriach funkcji i użyteczności w stosunku do całości społecznej. Przy milczącym założeniu, że takowe całości społeczne w ogóle istnieją i możemy je poznać w stopniu na tyle dostatecznym, żeby powoływanie się na nie posiadało jakiś racjonalny sens ${ }^{8}$. W pewnym ogólnym zarysie mamy raczej do czynienia z sytuacją występowania zjawiska inżynierii bez inżyniera, co czyni analogię z procesem wytwarzania technologicznego wątpliwą, z punktu widzenia jej trafności. Inżynierowie społeczni posiadają pewną zaskakującą cechę, to znaczy nie posiadają tożsamości indywidualnej, ponieważ nie traktują samych siebie jako autorów tego, co czynią. Zwłaszcza wtedy, gdy pojawia się kwestia odpowiedzialności za działania, które podejmowali, ale wobecktórych post factum zyskują niezwykły dystans, który możemy zdiagnozować jako typ alienacji pragmatycznej ${ }^{9}$. Mamy zatem do czynienia ze wzorcem postępowania, który funkcjonuje raczej na poziomie społecznej nieświadomości.

Z punktu widzenia teorii polityki Arendt, powyższy proces socjalizacji (inaczej możemy go określić jako proces uwspólniania człowieka) poprzez mechanizmy biurokratyczne wynika z zaniku granicy pomiędzy sferą publiczną i prywatną. Granica powyższa posiada przede wszystkim charakter kulturowy, ale jest również uchwytna na poziomie wzorców zachowań, które determinują sposoby rządzenia. Zakładamy, że najistotniejszym aspektem w tego typu analizie, która interpretuje kulturę, jako sferę informacji o tym co, w jaki sposób i dlaczego robić, jest aspekt epistemologiczny. Stąd adekwatnym terminem dla jej określenia jest epistemologia kontroli, dla której podstawowym podziałem są rozróżnienia stosowane przez Arendt. Stosujemy tu pojęcia kontroli w odniesieniu zarówno do poziomu autonomii aktorów społecznych i politycznych, jak i w stosunku do możliwej do uzyskania informacji aktorów w stosunku

7 Przegląd teorii biurokracji znajdziemy w: Encyklopedia socjologii, t. 1, Warszawa 1998, s. 67.

8 Jeden z najwybitniejszych teoretyków współczesnego funkcjonalizmu w naukach społecznych traktuje istnienie systemów społecznych jako artykuł wiary. Zob. N. Luhmann, Systemy społeczne, przekł. M. Kaczmarczyk, Kraków 2007, s. 19-22.

${ }^{9}$ Sprawa Eichmanna, którą Arendt analizowała w swoim słynnym eseju, posiada swoje teoretyczne uzasadnienie w pracy R. Hilberga wyjaśniającego zagładę w kategoriach teorii biurokracji, zob. R. Hilberg, Zagłada Żydów Europejskich, t. 1, Warszawa 2018. 
do siebie, jak i w stosunku do innych aktorów. Innymi słowy, pytając o to, kto kogo kontroluje i może kontrolować, próbujemy jednocześnie ustalić jaką potencjalnie informację o sobie mogą uzyskać aktorzy. Podstawowym podziałem jaki przyjmuje tu Arendt jest podział na aktorów i obserwatorów, traktowany jako podział ról, a nie grup społecznych. Czyli, w zależności od sytuacji lub przyjmowanej perspektywy, każdy z podmiotów jest aktorem lub obserwatorem w pewnym sekwencyjnym układzie. Jest też trzecia perspektywa, którą przyjmuje w swoich analizach sama Arendt, czyli perspektywa meta-obserwatora, która jest analogiczna z sytuacją każdego analityka próbującego rozświetlać nieprzejrzystości poznawcze życia publicznego ${ }^{10}$.

Powyższe rozróżnienia pozwalają nam uchwycić charakter interakcji pomiędzy aktorami (podmiotami działającymi) zarówno na poziomie bezpośrednim, jak i w sytuacji, gdy relacje pomiędzy nimi ulegają zapośredniczeniu. To co charakteryzuje sferę społeczną, która zgodnie z ujęciem historycznym polityki przez Arendt zdominowała ją współcześnie, jest zapośredniczenie relacji pomiędzy aktorami poprzez układy interesów. W stosunku do klasycznego ujęcia polityki, w którym jest ona konstytuowana w sferze publicznej poprzez działania wolnych podmiotów (obywateli), podstawowa różnica sprowadza się do tej, jaka istnieje pomiędzy nakazem a inicjatywa.

Zanim przejdziemy do dalszej analizy, która pozwoli lepiej zrozumieć ten heurystyczny skrót, zwróćmy uwagę, że stanowisko Arendt w odniesieniu do społeczeństw i zależności społecznych, budzi często nieporozumienia z powodu odmiennej perspektywy jaką ona konsekwentnie przyjmuje. Jest ona odmienna zwłaszcza na poziomie aksjologicznym, ponieważ zwykle postawy, które określamy mianem społecznych czy prospołecznych są wartościowane pozytywnie, gdyż podkreślają ludzką zdolność do współpracy. Z punktu widzenia Arendt społeczeństwo jest zjawiskiem naturalnym i stąd nie posiada jakiś szczególnych walorów politycznych, gdyż jest koniecznym przedłużeniem biologicznego wymogu pracy ${ }^{11}$. Z punktu widzenia interesującego nas tu problemu istotne jest to, że relacje społeczne nie są kwestią wyboru, bo taki jest sens definiowania człowieka jako zwierzęcia społecznego. W związku z tym Arendt interesuje charakter relacji politycznych, które w tym kontekście traktuje jako rezultat organizacji społecznej. Taz kolei może przybierać różne formy, ponieważ

10 Por. H. Arendt, Myślenie, przekł. H. Buczyńska-Garewicz, Warszawa 1991, s. 139 i n.

11 M. Passerin d'Entreves, The Political Philosophy of Hannah Arendt, Routledge 1994, s. $46 \mathrm{i} \mathrm{n.}$ 
możemy je modyfikować. Dopiero na tym poziomie możliwości mamy do czynienia z organizacją polityczną. Oczywiście pomiędzy tak wyodrębnionymi relacjami istnieją również zależności, a nas w tym wypadku będzie interesować wpływ procesu uspołecznienia na procesy polityczne. Wpływ, który możemy również śledzić na poziomie przedefiniowywania samej polityki w świecie współczesnym, który w stopniowy sposób zmienił samo rozumienie polityki. Ten ogólny obraz sytuacji musimy uzupełnić o jeszcze jeden element, to znaczy wspominaną już technologię, która jest istotna dla kształtowania społeczeństwa na dwóch paralelnych poziomach. Pierwszy, to czysto fizyczne manifestacje technologii, które podobnie jak nasze ciała narzucają nam warunki codziennej egzystencji. Ostatnią taką manifestacją jest komputer wraz z siecią, który coraz częściej pełni również rolę zastępczą w stosunku do człowieka. Drugi poziom, to sposób myślenia o świecie w kategoriach zasobów i produktów, które zgodnie z logiką instrumentalną możemy zawsze wytworzyć. Zgodnie z nią również ludzie są typem zasobu, który możemy wykorzystać do osiągnięcia z góry nakreślonego celu, rozstrzygającego o funkcji (przydatności) ludzi ${ }^{12}$.

\section{Klasyczny wzorzec tyranii i proces jego sublimacji: tyran bez twarzy i imienia}

Tyrani w społecznej wyobraźni to najczęściej figury na poły mityczne, również wtedy, gdy posiadają swoje precyzyjnie określone odpowiedniki historyczne. Mityczność tyranów wynika z wielu kulturowych uwarunkowań, ale w kontekście racjonalnie rozważanego sprawstwa jest pochodną dwóch cech przypisywanym tymże postaciom. Pierwsza to dysproporcjonalny poziom sprawstwa, a druga to zakres wiedzy jakim owe figury dysponują. Zgodnie z powszechnym przekonaniem, zarówno w odniesieniu do aktualnego stanu rzeczy, jak i w stosunku do przyszłości, która to wiedza czyni ich wyjątkowymi bohaterami historii. W zależności od momentu historycznego i obowiązującej ideologii bywają uznani za przedstawicieli dobra lub zła, których sens wykracza poza racjonalnie rozumianą etykę. Taki obraz tyranii jest rodzajem kulturowego archetypu, w którym zawierają się rysy warte zachowania na poziomie teoretycznej analizy, który możemy przywołać już z klasycznej filozofii polityki ${ }^{13}$. Tyraniajest

12 Por. Kondycja..., s. 169.

13 Por.P.Kłoczowski, Bitwa ksiq̨̇̇ek. Konfrontacja Arystotelesa znowożytnafilozofia politycznq, Kraków 2007, s. 19 i n. 
tu uznawana za typ ustroju zdegenerowanego ze względu na woluntaryzm (arbitralność decyzji) rządzącego, rozumiany jako opozycja w stosunku do rządów prawa lub też ze względu na sposób rządzenia realizujący wyłącznie interesy rządzącego. Tyran z tego punktu widzenia nie musi być jedną osobą, ponieważ reprezentuje jedynie pewien styl rządzenia z określoną struktura podporządkowania i podejmowania decyzji.

Tak zarysowany obraz tyranii możemy teraz zastosować do właściwej analizy zjawiska tyranii, która jest zbiorem relacji pomiędzy ludźmi. Innymi słowy, tyrania jest zjawiskiem społecznym kształtowanym na poziomie egzystencjalnych zależności pomiędzy ludźmi, które są rezultatem naturalnych i ukształtowanych asymetrii (nierówności) pomiędzy nimi. Struktury społeczne (na poziomie wyobraźni) mogą przybierać rożnego typu formy, włącznie ze strukturami sieciowymi, w których trudno mówić o oczywistych hierarchiach. Ale w znanych nam historycznie społeczeństwach zawsze występowały struktury pionowe wynikające z podporządkowania. Stąd na poziomie kulturowym, Arendt wywodzi rozumienie struktur dominacji ze struktur rodzinnych. Rzymski dominus pozostaje do dziś archetypem suwerenności utożsamianej z władzą najwyższą lub też ostateczną, która z pragmatycznego punktu widzenia nie jest niczym innym, jak możliwością decydowania o życiu i śmierci. W utopijnych interpretacjach, których powszechność dowodzi stałej obecności myślenia utopijnego w polityce, przybiera formę sprawstwa, która sama leży poza światem przyczyn, skutków, zależności i współzależności. Podobnie jak w przypadku sporów o miejsce woli w strukturze przyczynowej świata, włącznie z teoriami woli politycznej, mamy tu do czynienia z paradoksem, w którym wola jako przyczyna zdarzeń w świecie, nie posiada przyczyn poza samą sobą ${ }^{14}$.

Teza o relacjach społecznych jako wykazujących podobieństwa z klasyczną tyranią może się wydawać zbyt radykalna, jeśli myślimy o tej ostatniej wyłącznie w negatywnych kontekstach. Spróbujmy zatem dla równowagi wyobrazić sobie dobrego tyrana, który przypominabardziej figurę opiekuńczego ojca, który wie, co jest dobre dla jego dzieci i zrobi wszystko, aby je uszczęśliwić, zgodnie z własną wizją. Włącznie z zasto-

14 Arendt nie wywodzi zjawisk politycznych z fenomenu woli, głównie ze względu na publiczny charakter tych pierwszych, ale też z powodu jej domniemanej rozkazodawczej funkcji. Polityka nie jest sferą rozkazów. Por. H. Arendt, Co to jest wolność?, [w:] H. Arendt, Między czasem minionym a przyszłym. Osiem ćwiczeń z myśli politycznej, Warszawa 1994, s. 184 i n. Dla porównania Carl Schmitt nie dostrzegał problemu w utożsamianiu woli i prawa, nadając temu ostatniemu charakter tyrański. Zob. R. Wonicki, Polityka władzy i wolności w myśli Carla Schmitta i Hannah Arendt, «Kronos» 2008, nr 3. 
sowaniem słusznej przemocy, której zasadności kiedyś dowodził Augustyn Aureliusz. Aby jeszcze bardziej wysubtelnić tę relację wertykalnej zależności do pary rodzic/dziecko, dodajmy dwie inne. Pierwsza to para nauczyciel/uczeń, a druga to autorytet/akolita. Nowoczesna biurokracja może być reprezentowana w postaci mniej oczywistego podziału. Ale możemy na mocy konwencji przyjąć, że mamy tu do czynienia z dwójką technokrata/laik. Technokrata jest specjalistą, ekspertem, a figura laika reprezentuje obywatela, które to pojęcie w kontekście technokratycznych instytucji w zasadzie straciło jakikolwiek walor. Powyższe rozróżnienia przedstawiają nam zależności, które, przynajmniej w założeniu, wynikają z nierówności poznawczej podmiotów. Przywołując tutaj wcześniej wprowadzony termin, epistemologię kontroli, możemy powiedzieć, że na poziomie faktycznym kontrola A nad B wynika $\mathrm{z}$ innego poziomu wiedzy. W małych skalach społecznych (rodzina, szkoła itp.) jest to w dużej mierze zasadne twierdzenie i odnosi się ono do trzech pierwszych par. Ponadto małe skale społeczne wymagają stosowania innych środków, do czego jeszcze wrócimy, oraz wiedzy, która jest dużo mniej problematyczna, niż w przypadku pary technokrata/laik. Technokrata zarządza procesami społecznymi i nawet jeśli uznalibyśmy, że istnieje adekwatny typ wiedzy, aby mógł on to robić, to wcale nie jest oczywistą odpowiedź na pytanie, czy powinien to robić.

Spójrzmy teraz na strukturę społeczną w interpretacji, która $\mathrm{z}$ wielu względów wydaje się być jej najbardziejliberalną wersją, czyli jak na strukturę wymiany. Arendt twierdzi, że praca i jej pochodne są zależnościami koniecznymi, ponieważ od nich zależy nasza egzystencja. Podobnie jak tyrania polityczna tworzyła niewolników za pomocą środków przemocy, tak konieczność pracy tworzy niewolników, choć metodami bardziej wyrafinowanymi. Dla Arendt nie są tu istotne konotacje historyczne tychże pojęć, ale zależności, które one desygnują. Tyrania polityczna pozbawiona skarbca też szybko traci podstawy swojej egzystencji, ponieważ to ekonomia rozstrzyga o możliwości istnienia każdego systemu społecznego.

Wróćmy teraz do idei społeczeństwa jako systemu wymiany, które to pojęcie z kolei posiada bardzo pozytywne konotacje i na poziomie znaczenia jest utożsamiane z byciem społecznym (zatem ktoś, kto nie uczestniczy w wymianie jest społecznie nieprzystosowany i wymaga reedukacji). Konotacjejednak nie likwidujązależności, ponieważ znalezienie się poza systemem wymiany oznacza degradację i ostatecznie śmierć. System wymiany z kolei podlega kontroli pośredniej i bezpośredniej za pomocą instytucji pieniądza. W tym właśnie miejscu możemy odnaleźć bijqce serce systemu biurokratycznego. Technokrata, której to postaci możemy 
też przypisywać inne jeszcze kompetencje, jest niewątpliwie specjalistą w dzieleniu funduszy. W kategoriach władzy i kontroli, które nas tu zajmują, jest to oczywiście władza najwyższa, ponieważ kontroluje system oraz pośrednio lub też bezpośrednio może rozstrzygać o miejscu każdego w systemie wymiany. Oczywiście posiada również środki do budowania poparcia w sferze publicznej, która z jego punktu widzenia przypomina bardziej teatr marionetek.

Na poziomie ogólnym, teza Arendt w odniesieniu do bezosobowej tyranii jako nowoczesnym fenomenie, zawiera w sobie założenie o prywatności relacji społecznych. Wynika ona z faktu prywatności potrzeb (interesy są pochodną potrzeb) oraz subiektywnego charakteru wszelkich doświadczeń. Nie chodzi przy tym to, że ludzie nie są w stanie uzgodnić wspólnej sfery interesów. Chodzi o to, że zasady, które rządzą sferą interesów zastosowane w sferze instytucji publicznych zupełnie zmieniają charakter tych ostatnich, ponieważ nabierają jedynie charakteru dekoracji. Nie zmienia tego stanu rzeczy nawet fakt, że mistrzowie marionetek zmieniają się w różnych cyklach. Na miejscu pozostaje zawsze technokrata, reprezentujący określony typ wiedzy, stąd też nie posiadający twarzy jako znaku indywidualnego istnienia. Jest jak bohater powieści Stanisława Lema, który występuje nie pod własnym imieniem, ale jako Fizyk, Chemik czy Ekonomista. Możemy zasadnie podejrzewać, że brak imienia jest w przypadku technokraty zaletą, bo jest elementem stanowiącym o przewadze w grze interesów, bez konieczności wikłania się w zasady odpowiedzialności za podejmowane decyzje.

\section{Wzorce zachowań a modele racjonalności}

Wróćmy teraz do idei przestrzeni kulturowej, którą określiliśmy jako zbiór możliwych wzorców zachowania, które ze względu na różne, zewnętrzne wobec nich czynniki mogą mieć większe lub mniejsze szanse na realizację. Włączmy w zakres tej przestrzeni instytucje polityczne, które w istotnym swoim aspekcie nie są niczym innym jak kulturowymi wzorcami zachowań, podlegającymi lokalnym i czasowym reinterpretacjom. Nawet jeśli w ich rozumieniu dominuje aspekt symboliczny, to nadal pełnią rolę kulturowych wskaźników zachowań. Wymiar symboliczny może stać się ich wymiarem podstawowym w wypadku, gdy mamy do czynienia $\mathrm{z}$ instytucjami zapożyczonymi i wprowadzonymi w trybie prawodawczym. W tych warunkach może powstać rozdźwięk pomiędzy ich pierwotnym sensem, a sensem faktycznie realizowanym. 
Z punktu widzenia myślenia ewolucyjnego najistotniejsze jest wskazanie na mechanizm generowania wzorców zachowań, w tym jego źródło oraz na mechanizm selekcji, który rozstrzyga o rozprzestrzenianiu się pewnego wzorca na poziomie kulturowym ${ }^{15}$. W ramach ewolucji kulturowej takie zmiany mogą dotyczyć krótkich okresów, krótszych niż standardowo rozumiane pokolenie, oraz podlegać celowym modyfikacjom. Zachowanie, w pewnym przybliżeniu, jest funkcją dwóch zmiennych, czyli środowiska i instrumentarium, którym dysponuje podmiot. Przez instrumentarium rozumiemy tu narzędzia fizyczne, ale przede wszystkim uposażenie intelektualne, które jest w zasięgu podmiotu. Począwszy od językowejinterpretacjiśrodowiskapozdolność rozwiązywaniaproblemów w tymże środowisku ${ }^{16}$. Arendt również podkreślała znaczenie tego sprzężenia pomiędzy rozumieniem świata i swojej sytuacji przez człowieka a narzędziami, nie tylko w kontekście codziennych czynności, ale również w kontekście rozwoju nauki ${ }^{17}$. Stąd też czerpią swój sens podziały, jakie wprowadziła pomiędzy pracą (labour), wytwarzaniem(work)a działaniem (action). Występuje pomiędzy nimi różnica środowiska i środków. za pomocą których realizujemy poprzez nie swoje cele. Efektywnym zachowaniem, zwłaszcza w potocznym rozumieniu, jest jedynie proces wytwarzania, który nie jest niczym innym jak implementacją konkretnej idei. Każdy inny typ jest angażowaniem się w procesy, które z natury rzeczy nie posiadają swojego zakończenia, a przewidywanie ich przebiegu, jeśli w ogóle jest możliwe, bywa bardzo trudne. Proces, który związany jest z zachowaniami politycznymi to historia, która zgodnie z dystynkcjami Arendt, jest efektem ludzkiej zdolności do działania.

$\mathrm{Z}$ punktu widzenia problemu biurokracji najistotniejszy jest wzór racjonalności, który wyrósł z procesu technologicznego. Biurokracja, interpretowana przez Arendt jako ostateczny etap uspołecznienia człowieka, jest również sposobem na zniesienie historii lub też próbą technologizacji historii. Z perspektywy historii idei, moglibyśmy tu mówić o typie technologicznego Heglizmu. Ale wróćmy jeszcze do poziomu podstaw tego typu myślenia. Technologia jest syntezą dwóch typów zachowań, czyli pracy i wytwarzania. To pierwsze posiada charakter procesualny, a drugi jest archetypem jednostkowej czynności. Praca w wyniku syn-

15 Por. L. Stone, P.F. Lurquin, Geny, kultura i ewolucja człowieka, przekł. W. Branicki, W. Więckowski, Warszawa 2009, s. 167 i n.

16 Na temat roli narzędzi w procesie myślenia zob. D.C. Dennett, Dźwignie wyobraźni i inne narzędzia do myślenia, przekł. Ł. Kurek, Warszawa 2015, s. 9 i n. oraz tenże, Natura umysłów, Warszawa 1997.

${ }^{17}$ Kondycja..., s. 279 i n. 
tezy nabrała charakteru technologicznego na skutek zastosowania reguły podziału na jednostki, które są sensowne z punktu widzenia całości (perspektywa inżyniera lub innego konstruktora), ale z punktu widzenia jednostek mogą stanowić prostą, pozbawioną znaczenia czynność. Przypominamy ten elementarz technologiczny ze względu na atrakcyjność wzorca, który przy różnych modyfikacjach przechowuje tę podstawową ideę. Otóż zgodnie z nią, każdy typ przedsięwzięcia możemy potraktować jako działanie społeczne, zachowujące zasadę podziału czynności i osiągający w sposób maksymalnie efektywny zakładany cel (końcowy produkt). Oczywiście każda z tych czynności musi stosować się do z góry określonych norm, które wiążą wykonującego daną czynność. Z oczywistych powodów jedyną stroną $\mathrm{w}$ tym procesie, która posiada pewien zakres swobody jest konstruktor/projektant.

Ten schemat oczywiście nie może budzić szczególnych kontrowersji wtedy, gdy mówimy o linii produkcyjnej samochodów. Ale spróbujmy przełożyć ten schemat na technologię wynalezienia samochodu, a przekonany się, że jego efektywność, która jest miarą racjonalności tego wzorca postępowania jest zbliżona do zera. Historia nauki i technologii to historia przypadków, genialnych olśnień, irracjonalnych motywacji i przekonań ${ }^{18}$. Jak zgrabnie ujął to Karl Popper, kontekst odkrycia może być zupełnie nieprzejrzysty, ponieważ ma charakter historyczny na każdym poziomie, dlatego w nauce liczy się uzasadnienie. Od niego również wywodzi się reguła, która odnosi się do ewolucji idei, które powinny umierać za nas w wyniku racjonalnej krytyki. Pozostaje odpowiedzieć tylko na pytanie o kryteria racjonalności oraz czy racjonalność, zgodnie z wieloma interpretacjami posiada charakter uniwersalny. Jeśli przyjąć w naszym wywodzie za przesłankę wyniki badań nad zjawiskiem racjonalności, to uniwersalna racjonalność należy jedynie do świata postulatów teoretycznych. Natomiast racjonalność na poziomie pragmatyki, czyli w świecie decyzji, funkcjonuje jako korelat środowiska, w którym funkcjonuje podmiot ${ }^{19}$. Jest zatem zróżnicowana ze względu na rodzaje reguł, które stosują decydenci w danym środowisku.

Biurokracja, wbrew powyższym badaniom, odwołuje się do typu racjonalności technologicznej, który uchodzi za uniwersalny, ponieważ schemat, który jest przez nią reprezentowany spełnia powszechne kryteria

18 Por. R. Holmes, Wiek cudów. Jak odkrywano piękno i grozę nauki, przekł. E. Morycińska-Dzius, Warszawa 2010.

${ }^{19}$ Por. G. Gigerenzer, P.M. Todd i ABC Research Group, Zagadki heurystyk decyzyjnych,

Warszawa 2018, s. 25-35. 
rozumienia. Według Arendt, i trudno się z nią tu nie zgodzić, reguły racjonalności instrumentalnej wywodzą się z prostej logiki wytwarzania, którą odnaleźć możemy również w budowie i zastosowaniu cepa. Figura technokraty reprezentuje typ myślenia, który kiedyś wprowadził do nauk społecznych Skinner, wyobrażający sobie, że złożoność zachowań społecznych możemy wyjaśnić odwołując się do pary wzmocnień20. Problem z jego schematem polega między innymi na tym, że w pewnym sensie może być całkiem efektywny, o ile tylko technokrata dysponuje stosownymi środkami do jego implementacji.Zwłaszcza, jeśli w procesie wdrażania zadziała mechanizm sprzężenia zwrotnego, który sprawi, że założenia teoretyczne behawioryzmu nie tyle wyjaśnią złożoność ludzkich zachowań, co sprowadzą je do poziomu behawioralnego prymitywizmu. Wrócimy do tego wątku w kolejnym kroku.

\section{Memy w przestrzeni kulturowej: między refleksją a naśladowaniem}

Określiliśmy wcześniej przestrzeń kulturową jako przestrzeń informacji o możliwych do zrealizowania wzorcach zachowań. Jedną ze współczesnych interpretacji określającą charakter informacji w tejże przestrzeni jest teoria memów, która jest przykładem poszukiwania takiej jednostki informacji, która mogłaby podlegać analizie w ramach ewolucyjnego ujęcia zjawisk kulturowych ${ }^{21}$. Na potrzeby tej analizy możemy przyjąć, że pojęcie memu odpowiada bardziej klasycznemu pojęciu idei, jeśli tylko założymy, że sama idea może być reprezentowana poprzez różne nośniki, w tym przede wszystkim językowe, a nie odnosi się do Platońskiej interpretacji ontologii.

W teorii Arendt, która służy nam tu jako punkt odniesienia, idea nie jest niczym innym, jak pomysłem na to jak coś zrobić, czy też ukształtować, dla której powstania kluczowa jest działalność rzemieślnika czy artysty $^{22}$. Idee tak rozumiane podlegają różnym procesom przetwarzania, w obrębie zmiany sensów oraz kontekstów, w których zostają ponownie wykorzystane. Myślenie w ramach analogii i poprzez analogie

20 Por. B.F. Skinner, Poza wolnościq i godnościq, przekł. W. Szelenberger, Warszawa 1978, s. 25 i n.

${ }^{21}$ Por. S. Blackmore, The Meme Machine, Oxford 1999, s. 75-76; D.C. Dennett, Od bakterii do Bacha. O ewolucji umysłów, przekł. K. Bielecka, M. Miłkowski, Warszawa 2017, rodz. 13.

22 Por. H. Arendt, Myślenie... 
jest traktowane jako jeden z podstawowych mechanizmów poznawania świata, a szczególnie sposobem na twórcze rozwiązywanie problemów ${ }^{23}$. W innym ujęciu, zdolność czy predyspozycja do refleksji jest podstawową cechą wyróżniającą człowieka, w którym to akcie możemy przedmioty własnych myśli poddać rozważeniu na kolejnym poziomie (w bardziej technicznym żargonie chodzi o rekursywność myślenia). Refleksyjność jednak nie jest podstawowym sposobem przyswajania treści kulturowych, ale raczej ich ostatecznym i dość wyjątkowym trybunałem.

Podstawowym trybem przyswajania idei jest naśladownictwo lub kopiowanie, które nie wynika z rozważań o charakterze refleksyjnym, tylko jest wyrazem pragnienia mimetycznego ${ }^{24}$. Ten poziom kulturowego uczenia się jest powiązany z emocjami, ale nie powinniśmy traktować go jako z założenia irracjonalnego, ponieważ emocje są raczej szczególnym trybem myślenia (umysłu), a nie stanem człowieka, który jest rozłączny w stosunku do funkcji poznawczych ${ }^{25}$. Na potrzeby tej analizy możemy poprzestać na stwierdzeniu, że naśladownictwo jest bardziej ślepym procesem uczenia się, to znaczy takim, w którym bierzemy (prawdopodobnie) pod uwagę konsekwencje krótkookresowe, a nie bierzemy pod uwagę konsekwencji długookresowych. Wynika to z braku możliwości lub też zaniechania testowania idei $\mathrm{w}$ sferze publicznej. Testowanie w sensie ścisłym wyróżnia tylko naukę, ale nawet w społeczeństwach nowoczesnych jej funkcja modyfikatora przekonań ludzi jest dość ograniczona. Taką funkcję w życiu publicznym mogłaby spełniać racjonalna debata, ale instytucjonalnej platformy do niej mogłyby dostarczyć jedynie media publiczne. Przy ich braku lub ograniczonym zasięgu rozstrzygają inne czynniki, które regulują przekaz kulturowy.

Memy, które się rozprzestrzeniają w przestrzeni kulturowej posiadają cechy, które czynią je atrakcyjnymi poza sferą racjonalnej debaty. Atrakcja,czylijakiś typ przyciqgania pomiędzy elementami świata wskazujena występowanie relacji zgodności pomiędzy nimi, aktualnej czy też potencjalnej. W wypadku atrakcji rozpatrywanej na poziomie emocjonalnym jej

23 Por. D. Hofstadter, E. Sander, Surfaces and Essences: Analogy as the Fuel and Fire of Thinking, Basic Books, New York 2013.

$24 \mathrm{~W}$ antropologii kultury mechanizm mimetyczny jest podstawowym wzorcem wprowadzonym przez R. Girarda, zob. R. Girard, Poczqtki kultury, przekł. M. Romanek, Kraków 2006, s. 61 i n. Ale mimetyka jako zjawisko jest powszechniej występującym mechanizmem upodobnienia się w relacji do czegoś.

25 Por. A. Damasio, The Strange Order of Things: Life, Feeling, and the Making of Cultures, Vintage 2018; M. Minsky, The Emotion Machine. Commonsense Thinking, Artificial Intelligence, and the Future of the Human Mind, Simon \& Schuster, New York 2007. 
źródłem jest doświadczenie przyjemności. Wydawałoby się, że zabrnęliśmy w tym miejscu w ślepą uliczkę w naszym wywodzie, ponieważ zjawiskobiurokracji,które doczekało się kiedyś pozytywnej oceny w socjologii Webera, jako wyraz społecznej racjonalności, w przestrzeni publicznej jest wartościowane neutralnie lub negatywnie. W jaki zatem sposób może stanowić społeczna atrakcję.

Sięgnijmy znów w tym miejscu do stanowiska Arendt i jej diagnozy społeczeństwa nowożytnego, które wchłania sferę publiczną. Możemy wskazać na dwie rzeczy, które pomogą nam wyjaśnić ten pozorny paradoks. Po pierwsze, jest to zmiana odnosząca się do wartości pracy. Nie tylko na poziomie ekonomicznym, ale również na poziomie kulturowym, w tym etycznym, włącznie z teoriami społecznymi, które definiują człowieka poprzez pracę. Drugi element to idea porządku społecznego rozumianego jako społeczny podział pracy, którego paradygmatycznym przykładem jest taśma produkcyjna. Jeśli zakładamy, że każdy społecznie użyteczny człowiek pracuje (zauważmy jak trudno uciec od tego języka), włącznie z politykami, artystami i naukowcami, to ci którzy nie są w stanie udowodnić, że to robią, stają się społecznie bezużyteczni, czyli zbędni. Ten swoisty redukcjonizm prowadzi również do konkluzji, że bycie obywatelem polega na możliwości bycia obsłużonym w urzędzie. Praca stała się synonimem każdego rodzaju działalności, a jeśli tak, to możemy ustalić uniwersalne normy dla wszystkich uczestników tego społecznego ula. Normowanie pracy, aby domknąć ten wątek, jest sprzężone z produktem i w konsekwencji dochodzimy do sytuacji, w której wszystko jest produktem. Jeśli na przykład kształcenie uniwersyteckie jest produktem (również dlatego, że musi się sprzedawać), to w pewnym sensie również absolwenci uniwersytetów są produktami. Absurdalność, którą możemy dostrzec w tym fakcie, na poziomie nawet tak podstawowej refleksji, nie jest jednak powodem do odrzucenia idei podstawowej, ponieważ jej atrakcyjność staje się instrumentem wpływów politycznych. Ludzie pragną równości, rozumianej jako identyczność choćby na poziomie jednego aspektu. Udowodnienie przydatności w takich sytuacjach nie ma charakteru racjonalnych argumentów, ale polega na próbie wykazania podobieństwa do innych: trzeba się choćby retorycznie upodobnić, żeby nie zostać odrzuconym.

Naszym podstawowym memem nie jest zatem biurokracja, ale równość. Zkolei równość, w sensie opisanym powyżej, możemy uzyskać tylko za cenę normalizacji, czyli dzięki ustanowieniu wspólnej miary. Problem tego, na ile te prawidłowości przebiegają w różny sposób w systemach, które odwołują się do tak zwanego spontanicznegoładu lub też systemach 
politycznych zbiurokratyzowanych w ramach skonstruowanego modelu władzy pozostawiamy na boku, choć oczywistym jest, że każdy monopol może te tendencje wzmacniać. Podtrzymujemy jednak twierdzenie, że źródłem samego trendu nie są ideologie, ale sama dynamika społeczna, która pozbawiona instytucjonalnych granic działa przede wszystkim mechanizm skłaniający do konformizmu. Dla Arendt takimi granicami były instytucje cieszące się autorytetem, ale sam autorytet rozumiany jako zjawisko polityczne (publiczne) stracił na znaczeniu, czyli przeszedł do świata minionych wartości ${ }^{26}$. W jego miejsce pojawiła się logika strategii politycznych opartych na publicznie akceptowanych ideach, które stanowią podstawę rządów biurokratycznych. Trudno oprzeć się zniewalającej sile perswazyjnej idei porządku opartego na równości, w którym wszyscy podlegają tym samym kryteriom oceny. Na poziomie psychologicznym jest to skorelowane ze społecznie ugruntowaną potrzebą rządzenia innymi za pomocą nakazów, której główną funkcją jest upodabnianie do znanego, czyli do samego siebie. Sprzężenia zwrotne prowadzą ostatecznie do uśredniania $\mathrm{i}$ w ten sposób norma nie jest niczym innym jak przeciętnością 27.

Rzecz w tym, że drugą stroną tego medalu jest budowanie systemu kontroli, który ów porządek egzekwuje, co jest oczywistą korzyścią dla tych, którzy całym systemem zarządzają. Pozorna zbieżność interesów pomiędzy zarządcami a zarządzanymi (rozgrywana w sferze publicznej, która jest już tylko sferą medialną), pozwala tym pierwszym na zbudowanie takiej przewagi strategicznej, która wyklucza zmianę samego systemu. Przypomnijmy tutaj figurę naszego technokraty, który reprezentuje prostotę myślenia, charakterystyczną dlapierwszegobehawioryzmu. Technokrata dysponuje prostym narzędziem do sterowania złożonością systemów społecznych, czyli środkami finansowania. Nie jest ekspertem od zarządzania przyszłością społeczeństw, ale raczej przeciętnie sprawnym statystykiem, który eliminuje wszystko to, co lokuje się poza normami ustanowionymi w ramach systemu. Popularność idei jest zatem nie tylko kwestią ich atrakcyjności, ale również wynikiem celowych strategii stosowanych przez technokratów. Jeśli nie są one założone w ramach takich planów, to pozostaje nam przypisać ich realizacje ślepemu instynktowi naśladownictwa.

\footnotetext{
${ }^{26}$ Por. H. Arendt, Co to jest autorytet?, [w:] tejże, Między czasem minionym a przyszłym. Osiem ćwiczeń z myśli politycznej, Warszawa 1994.

27 Obserwacje Alexisa de Tocqueville’a nadal pozostają w mocy, a psychologia społeczna mogła je jedynie potwierdzić: jednomyślność to plaga demokratycznego, egalitarnego społeczeństwa, choć powyższa teza wydaje się kontrintuicyjna.
} 
Technologia społeczna w ujęciu Arendt jest nowym typem procesu, a to znaczy, że istnieje radykalna dysproporcja (asymetria) pomiędzy jego siłą, która go napędza a jednostkowymi aktami sprzeciwu. Idea porządku społecznego wraz z utylitarną retoryką dobrze się sprzedaje na tak zwanym rynku politycznym, którego siła jest wzmacniana poprzez rozwój technologii internetowych. Nadzieje, które pojawiły się w początkach rozwoju tego nowego medium, dotyczące powrotu do greckiego rozumieniu polityki (Arendt), jako swobodnej deliberacji, ale póki co pozostają niespełnione ${ }^{28}$. Bezpośrednia równość ludzi wynikająca z faktu partycypacji w zgromadzeniach na Agorze, nie posiada swojego odpowiednika w sieci, która jedynie zwiększyła możliwość sterowania zachowaniami politycznymi przez anonimowych pośredników.

\section{Zakończenie}

Pozostając w obrębie figur kulturowych, które zawierają w sobie pewne style i sensy działania, moglibyśmy dojść do konkluzji, że uspołecznionej sfery publicznej nie uratuje nawet armia Don Kichotów. Indywidualność, zwłaszcza ta o twórczym charakterze, może przetrwać tylko w niszach instytucjonalnych, ale trend w postaci ekspansji sfery społecznej prowadzi do ich marginalizacji. Arendt twierdziła, że polityka jest rodzajem sztuki performatywnej i podobnie jak ona jest równie ulotna. Ale tylko tak rozumiana polityka tworzy wspólny świat sensów, którego odpowiednikiem jest wspólna historia. Źródłem tej wspólnej narracji dla społeczeństwa nowoczesnego nie będzie ekonomia, ale też próby wskrzeszania mitów z przeszłości są daremną praktyką reanimacyjną.

\section{Bibliografia}

H. Arendt, Kondycja ludzka, przekł. A. Łagodzka, Aletheia, Warszawa 2000.

H. Arendt, Eichmann w Jerozolimie. Rzecz o banalności zła, Kraków 2010.

H. Arendt, Między czasem minionym a przyszłym. Osiem ćwiczeń z myśli politycznej, Warszawa 1994.

H. Arendt, Myślenie, przekł. H. Buczyńska-Garewicz, Warszawa 1991.

H. Arendt, O przemocy. Nieposłuszeństwo obywatelskie, Warszawa 1999.

H. Arendt, O rewolucji, przekł. M. Godyń, Kraków 1991.

S. Blackmore, The Meme Machine, Oxford 1999.

${ }^{28}$ Por. J.S. Fishkin, Democracy and Deliberation. New Directions for Democratic Reform, Yale University Press, New Haven 1991. 
A. Damasio, The Strange Order of Things: Life, Feeling, and the Making ofCultures, Vintage 2018.

D.C. Dennett, Odbakterii do Bacha. Oewolucji umysłów, przekł. K. Bielecka, M. Miłkowski, Warszawa 2017.

D.C. Dennett, Dźwigniewyobraźniiinnenarzędzia do myślenia, przekł.Ł. Kurek, Warszawa 2015.

D.C. Dennett, Natura umysłów, Warszawa 1997.

J.S. Fishkin, Democracy and Deliberation. New Directions for Democratic Reform, Yale University Press, New Haven 1991.

C. Gamble, J. Gowlett, R. Dunbar, Potęgamózgu. Jakewolucja życia społecznego kształtowała ludzki umysł, przekł. R. Kosarzycki, Kraków 2017.

G. Gigerenzer, P.M. Todd i ABC Research Group, Zagadki heurystyk decyzyjnych, Warszawa 2018.

R. Girard, Poczq̨tki kultury, przekł. M. Romanek, Kraków 2006.

J. Gleick, Informacja: bit, wszechświat, rewolucja, przekł. G. Siwek, Kraków 2012.

J. Golinowski, Perspektywa porzq̨dku postpolitycznego. Wstronę technologii władzy, Warszawa 2007.

M. Hetmański, Epistemologia informacji, Warszawa 2013.

D. Hofstadter, E. Sander, Surfaces and Essences: Analogy as the Fuel and Fire of Thinking, Basic Books, New York 2013.

P. Kłoczowski, Bitwa ksiqżek. Konfrontacja Arystotelesa z nowożytna filozofia politycznq, Kraków 2007.

M. Minsky, The Emotion Machine. Commonsense Thinking, Artificial Intelligence, and the Future of the Human Mind, Simon \& Schuster, New York 2007.

M. Passerin d'Entreves, The Political Philosophy of Hannah Arendt, Routledge 1994.

R. Przybylski, Sardanapal. Opowieść o tyranii. Na pożegnanie ohydnego stulecia, Warszawa 2001.

P.Richerson, R. Boyd, Not by Genes Alone: How Culture Transformed Human Evolution, Chicago 2006.

F.K. Salter, Emotions in Command: Biology, Bureaucracy, and Cultural Evolution, Rutledge 2017.

C. Schmitt, Lewiatan w teorii państwa Thomasa Hobbesa. Sens i niepowodzenie politycznego symbolu, przekł. M. Falkowski, Warszawa 2008.

B.S. Skinner, Poza wolnościq i godnościq, przekł. W. Szelenberger, Warszawa 1978.

L. Stone, P.F.Lurquin, Geny, kultura i ewolucja człowieka, przekł. W.Branicki, W. Więckowski, Warszawa 2009.

L. Strauss, O tyranii, przekł. P.Armada, A. Górnisiewicz, Kraków 2009.

M. Tomasello, Kulturowe źródła ludzkiego poznawania, przekł. J. Rączaszek, Warszawa 2002.

J.D. Villa, (red.), The Cambridge Companion to Hannah Arendt, Cambridge UP 2000.

F. de Waal, Chimpanzee politics: Power and Sex Among Apes, John Hopkins UP, Baltimore 2007.

R. Wonicki, Polityka władzy i wolności w myśli Carla Schmitta i Hannah Arendt, «Kronos» 2008, nr 3. 